\title{
The impact of Covid-19 pandemic on people's behavior and herbal drink (jamu) processing businesses in Banjarbaru, South Kalimantan
}

\author{
Susi Lesmayati*, Retna Qomariah, Awanis, and Lelya Pramudyani \\ South Kalimantan Assessment Institute for Agricultural Technology, Banjabaru, Indonesia
}

\begin{abstract}
This study aimed to determine and analyze the impact of the Covid-19 pandemic on (1) people's behavior to avoid exposure to the virus with consumed traditional herbal drink (jamu), and (2) jamu processing businesses in Banjarbaru City, South Kalimantan. The research location was determined purposively in the centre of traditional herbal drink processing known as Kampung Pejabat, Loktabat Selatan Village, South Banjarbaru District Banjarbaru City. The research was carried out from February to March 2021 and was conducted using a survey method to obtain primary data and supported by secondary data from reports and other sources. The data were analyzed descriptively. The studies showed that (1) Preventive efforts avoid the virus done by the peoples at the beginning of the pandemic until now by consuming jamu. Around $82-88 \%$ of people consuming jamu that they bought or made themselves, and they also consuming others in smaller amounts. The peoples already know the benefits of jamu as herbal medicine because it is a hereditary knowledge. Besides, consuming jamu gendong does not require a high cost. (2) there was an increase in volume production of jamu gendong around $100 \%$ at the beginning of the pandemic compared with production before the pandemic . The $\mathrm{R} / \mathrm{C}$ ratio of jamu processing is increased from 1,3 to 1,54 it means the pandemic had a positive impact on the jamu processing business.
\end{abstract}

\section{Introduction}

At the end of 2019, the world was shocked by a pandemic of a new disease. Later became known as the Coronavirus disease 2019 (abbreviated "Covid-19"). Covid-19 is an emerging respiratory disease caused by a novel coronavirus and was first detected in Wuhan, China. The condition is highly infectious, and its primary clinical symptoms include fever, dry cough, fatigue, myalgia, and dyspnea [1]. The ongoing Covid-19 epidemic has spread quickly, and by February 2020, the virus has reached 26 countries. In response to this challenging situation, the World Health Organization (WHO) declared it a public health emergency of international concern and called for collaborative efforts of all countries to prevent the rapid spread of COVID-19 [2]. In Indonesia, the government announced the first confirmation of the Covid-19 case in March 2020. However, based on the prediction of the

* Corresponding author: susilesmayati@yahoo.com 
expert team from the University of Indonesia's Faculty of Public Health (FKM UI), this virus has entered since January 2020. However, it is still locally transmitted [3].

Covid-19 sufferers can infect the spread of Coronavirus. This disease can be spread through tiny droplets from the nose or mouth when coughing or sneezing. Droplets then fall on the surrounding object. When others touch that contaminated object and touch their eyes, nose, or mouth, they can be infected with Covid-19. This matter can also happen if someone accidentally inhalation of droplets from the patient. That's why we need to keep a distance of at least one meter from the sick person [4]. As a new disease that has become a pandemic, Covid-19 must be watched for its relatively fast transmission, has a mortality rate that cannot be ignored, and there's no definitive therapy [5].

Specific vaccines and antivirals seem to be the best options to prevent Covid-19, but at the beginning of the pandemic, there was no medicine or vaccine available for Covid-19 [6]. Efforts to be discovered until mass produce can take a very long time; therefore, therapy in other ways must be sought. In another report, the integrative treatment between conventional medicines with the centuries-longstanding traditional ones, i.e., traditional Chinese Medicine (TCM), is helpful for Covid-19 treatment. These traditional medicine systems have been part of Asian people's life to treat any illness [7]. Ministry of Health of Indonesia advises the public to use traditional medicine as an effort to maintain health, prevent disease, and provide health care, including public health emergencies such as in the case of the COVID-19 pandemic [8], and WHO includes support for various innovation around the world including the use of traditional medicine [9].

Jamu is a traditional Indonesian herbal drink that still exists today and is supposed to have similar potential as those TCM [7]. The advantages of jamu include low toxicity and have mild side effects [10]. Jamu is made of natural ingredients whose types and properties are very diverse and used for generations for treatment based on experience. Some medicinal plants can be used n suggested for jamu ingredients and can be immunostimulatory agents to deal with COVID-19, reduce symptoms and overcome comorbid Covid-19 [11] based on the available safety and efficacy data. These medicinal plants are Curcuma longa (Turmeric), Curcuma zanthorrhiza known as Temulawak, Zingiber officinale or Ginger, Psidium guajava L, and Andrographis paniculata (Burm. F) Nees or known as Sambiloto [11,12]. In addition to the main ingredients, we can also add other ingredients to give flavor and aroma, such as cinnamon, lemongrass, and palm sugar [9].

This study aimed to determine and analyze the impact of the Covid-19 pandemic on people's behavior avoid exposure to the virus with consumed jamu, and analyze jamu processing business in Banjarbaru City, South Kalimantan. This study focused on the beginning of a pandemic and a year during a pandemic

\section{Methodology}

This study was carried out from February to March 2021 and was conducted using a survey method to obtain primary data. Data collection to determine people's or consumers' behavior in consuming jamu was done through an online system (WhatsApp group) and collected around 30 respondents from each sub-district in Banjarbaru, which are assumed to represent the community in general. In contrast, to jamu processing business, respondents are selected purposively in the center of jamu processing in Banjarbaru, known as Kampung Pejabat. The number of respondents involved in this survey is about $50 \%$ from families working as producers and sellers of jamu in Kampung Pejabat. The collected data are presented descriptively and complemented by secondary data from other reports and sources.

The data analysis method used to determine the impact of The Covid-19 pandemic on the jamu processing business is the Simple Partial Budget Analysis method. This method can be used to evaluate the performance of a technology [13]. The net income or profit is the 
difference between multiplying the amount of production and the price per unit of production with the total cost incurred in the production process. The formula for calculating profit is mathematical as follows :

$$
I=P \cdot Q-T c
$$

$$
\begin{array}{ll}
I & =\text { Profit } \\
P & =\text { production price per unit } \\
Q & =\text { production quantity } \\
T c & =\text { total cost of production }
\end{array}
$$

The efficiency level of jamu processing is done through revenue cost ratio ( $\mathrm{R} / \mathrm{C}$ ratio) analysis. If the $\mathrm{R} / \mathrm{C}$ ratio is $>1$, then the jamu processing business experiences a profit. On the contrary, if the $\mathrm{R} / \mathrm{C}$ ratio $<1$, it shares a loss, and if the $\mathrm{R} / \mathrm{C}$ ratio $=1$, it means the jamu processing doesn't experience any profit or losses. The $\mathrm{R} / \mathrm{C}$ ratio is a comparison between the revenue earned and the total costs incurred in the production process, with a mathematical formulation as follows :

$$
\begin{array}{ll}
R & =\text { revenue }=P . Q \\
T c & =\text { Total cost }
\end{array}
$$

\section{Results and discussion}

\subsection{Consumer behaviour on consuming jamu during the Covid-19}

The current state of the Covid-19 pandemic requires people to increase their awareness in maintaining health. The government has set some health protocols as outlined in the Decree of the Minister of Health No. HK.01.07/MENKES/382/2020 aims to continue to do the activity safely and not endanger others [14]. In addition to implementing health protocols, people also have to maintain their health and improve their immune systems. Efforts that can be made include exercising diligently, consuming nutritious food on the daily menu, and taking vitamin supplements or traditional herbal medicine (jamu). The use of herbal medicine or jamu as an alternative treatment is part of the community's indigenous knowledge. It is also carried out from generation to generation and cannot be separated from the role of parents in preserving culture [11]. Jamu has several advantages, such as low toxicity and mild side effects, relatively cheap $[10,15]$.

Related to the Covid-19 pandemic, consumers' attitude to intensify their immune system by consuming something is based on their needs and knowledge, reflected in their behavior. The conditions and desires of consumers vary greatly and can change due to the factors that influence consumers in conducting a consumption. There are several definitions of consumer behavior put forward by the expert. Consumer behavior is the action taken by individuals, groups, or organizations related to the decision-making process in obtaining and using economic goods or services that can affect the environment [16,17]. Consumer behavior is how an organization searches, buys, uses, evaluates, and disposes of products or services after consumption to meet their needs. Consumer behavior will be shown in several stages. There is the stage before purchase, purchase, and after purchase.

In this paper, a survey was conducted to overview the attitude and people's practices in improving their immune system during the Covid-19 pandemic, including consuming jamu and other foods. The survey was carried out online, and obtain the participants with the following characteristics as shown in the next Table 1. 
Table 1. Characteristic of the respondent

\begin{tabular}{|l|rl|c|}
\hline No & Characteristic & $\begin{array}{c}\text { Percentage } \\
(\%)\end{array}$ \\
\hline 1 & Gender & \\
& $-\quad$ Male & 17,6 \\
& $-\quad$ Female & 82,4 \\
\hline 2 & Ages (years) & 23,5 \\
& $-\quad 20-30$ & 32,4 \\
& $-\quad 31-40$ & 44,1 \\
\hline 3 & $-\quad 41>$ & - \\
& Level of education & 14,7 \\
& $-\quad$ Junior High School & 58,8 \\
& $-\quad$ Senior High School & 26,5 \\
\hline
\end{tabular}

From Table 1, it can be seen that the majority of those who filled out the online survey were women. It can happen because jamu as a herbal medicine has always been identified with women, especially beauty and reproductive health. While for the age, the majority of the respondent are from the age group of 41 years and above, this may indicate the level of awareness to maintain health mainly from exposure to the Covid-19 is in the adult group. And for the level of education, the majority come from undergraduate level deemed to have understood the benefits of jamu.

Figure 1 shows the types of food consumed by respondents to improve their immune system in the initial pandemic period (2020) compared to the range after one year of the pandemic. We can see that jamu has the highest percentage of food consumed at the pandemic onset and continues to increase until one year of the pandemic. It shows that the respondent can feel the benefits of consuming a jamu or herbal medicine on their body's resistance and supported by other food types such as fruits, vegetables, vitamin $\mathrm{C}$ supplements, and honey. From figure 1, it is also interesting to note that the use of vitamin $\mathrm{C}$ supplements has increased relatively high (about 12\%). It is probable considering the practicality of consuming it and the notion that high doses of vitamin $\mathrm{C}$ can prevent flu-like illness, where the symptoms of Covid-19 are identical to flu.

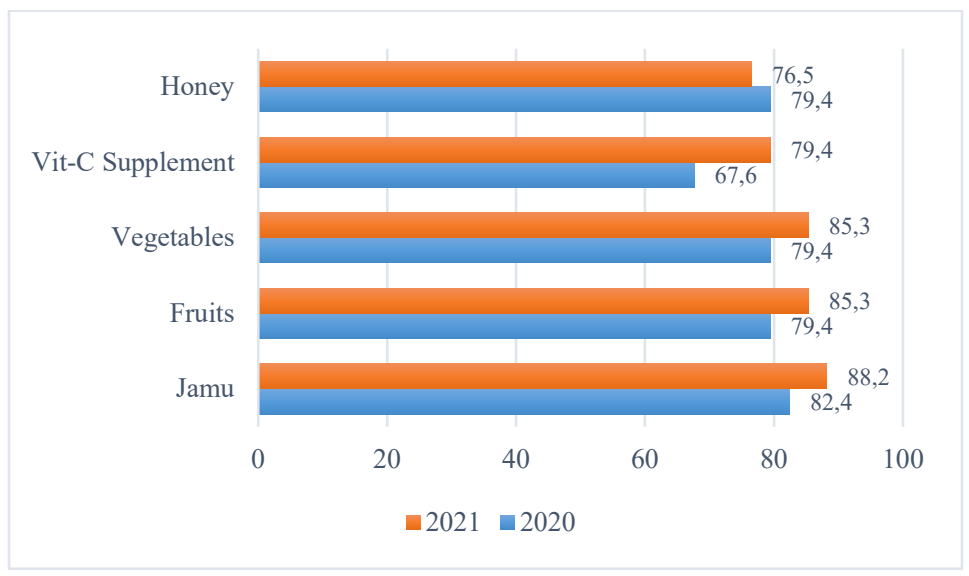

Fig 1. Types of food and beverages consumed

There are various ingredients to make jamu, such as rhizomes, flowers, leaves, etc. Respondent turned out to choose jamu made from rhizomes, which are easier to obtain. The 
literature found that active substance found in rhizome such as curcumin derived from turmeric can inhibit the uptake, replication, and production of influenza type A virus particles in vitro [18]. In figure 2 below, it can be seen the percentage of respondent's attitudes in choosing jamu ingredients.

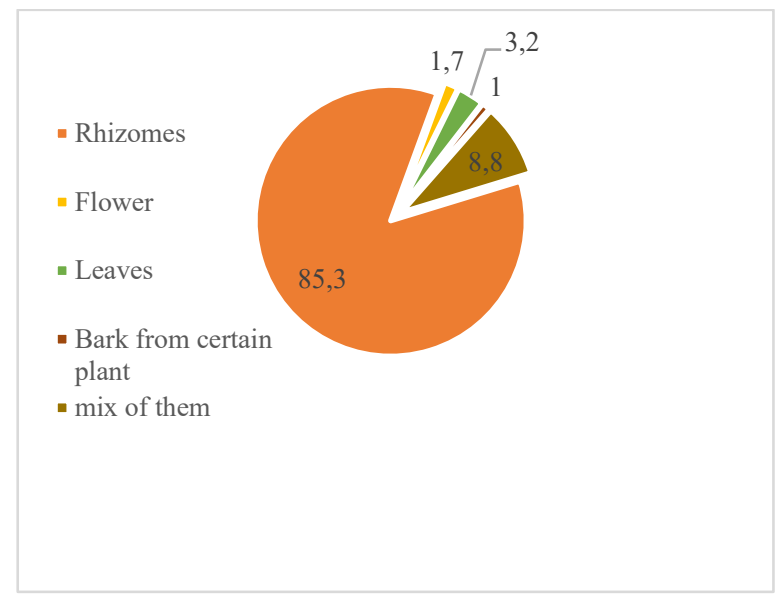

Fig 2. Respondents choice for jamu ingredient

From Figure 3, we can see how respondents obtain the jamu, where most of them choosing to buy jamu. The consideration is based on practicality. Sellers usually sell jamu regularly, and respondents have been customers before the pandemic Covid-19. Meanwhile, respondents who choose to make their jamu is more about the belief in food safety. By making their own, respondents feel more satisfied and safe with the products they consumed. There is no significant difference in the percentage of the respondent in how to get the jamu between 2020 and 2021.

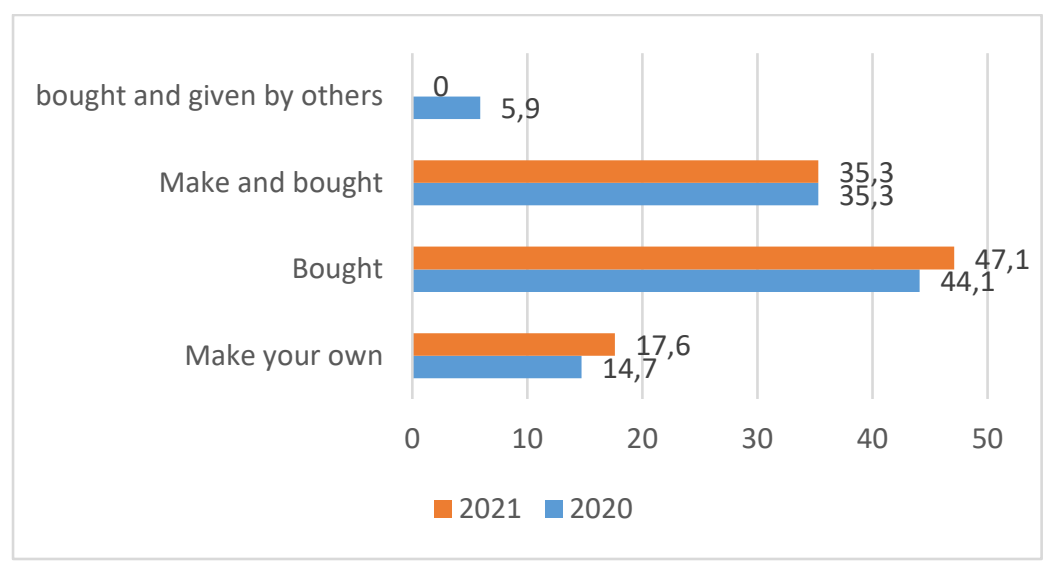

Fig 3. Respondents choose how to obtain jamu

A survey conducted well known that the respondents didn't prepare a particular budget for the consumption of jamu because they felt the price for jamu was mainly still accessible to them. As with the consumption of vitamin supplements, wherein the market has various kinds of vitamin supplements with varying prices, it is usually believed that the high cost of supplements also affects their effectiveness. So special budget must provide if they want to consume good vitamin supplements. 
Currently, there are many forms of traditional medicinal preparation such as extract in capsules, instant drinks, powdered herbs, and bottled jamu released by the industry. During 2020 and after one year of pandemic (2021), most respondents still choose jamu gendong as a drink to improve their immune system and their families. The reasons state that the jamu gendong is considered fresher than the bottled Besides, the prices of jamu gendong are lower. Figure 4 shows the percentage of respondents who choose jamu gendong beside the other form of traditional medicines.

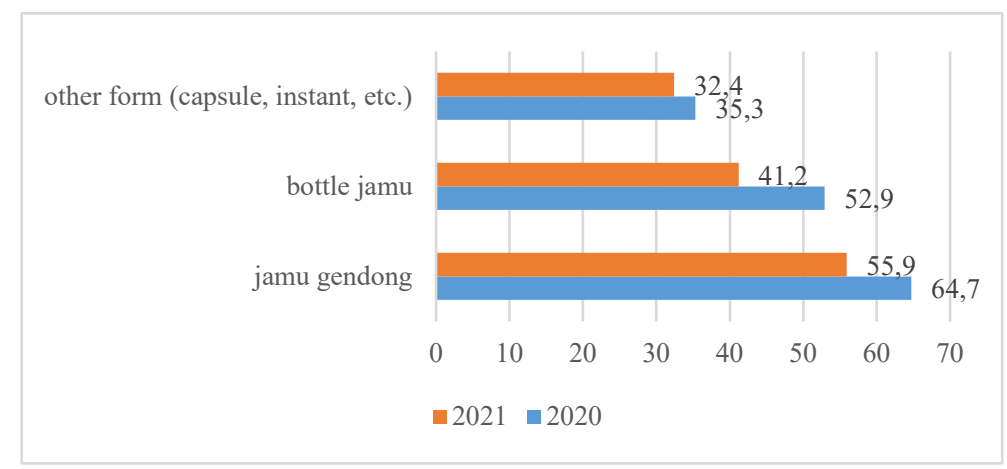

Fig 4. Choice of traditional medicine form

Attributes attached to jamu or herbal medicine are usually a consideration for the consumer to consume this product. There are efficacy and taste, packaging, price, information of producers, and so on. Figure 5 shows the attributes of jamu that consumers consider.

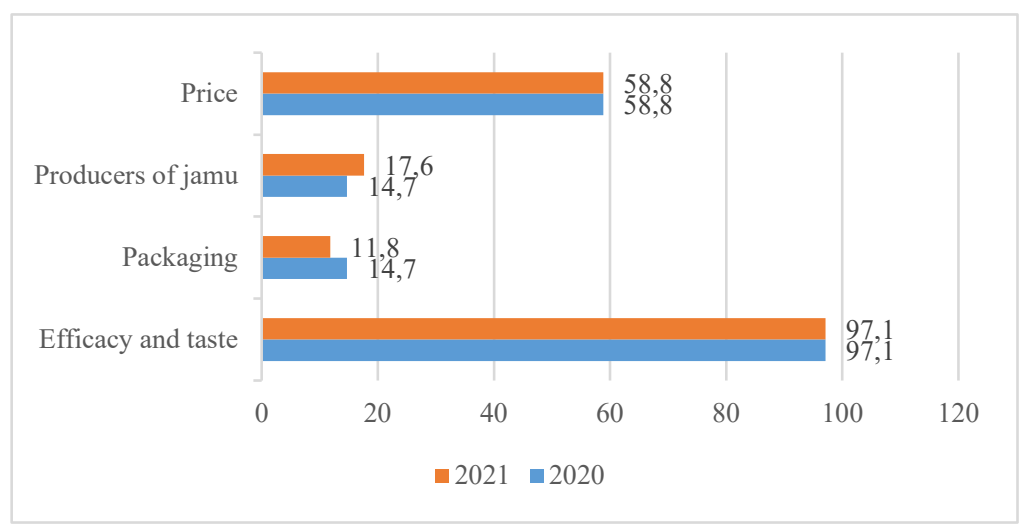

Fig 5. Attribute of jamu

In this study, as shown in Figure 5, the attribute that influences respondents to consume herbal medicine is its efficacy and taste. Buyers usually buy jamu gendong directly without using packaging, and they are familiar with the seller. What is felt most is the taste and efficacy of the product.

\subsection{Jamu processing business}

'Kampung Pejabat' is abbreviation of Kampung Pengolah Jamu Loktabat, which is located in Banjarbaru City, Province of South Kalimantan. The area of Kampung Pejabat was born from the ideas and initiatives of the residence. The name came from the fact that most of the residents work as producers and sellers of jamu. Of the 78 families, 33 of them work as jamu 
sellers. The residents are primarily immigrants from Solo, Central of Java. In 2017, the city government of Banjarbaru inaugurated the 'Jamu Cafe' locates in the Kampung Pejabat as one of the tourist destinations of Banjarbaru city. That makes the Kampung Pejabat more visited by local and foreign tourists. Table 2 showed us the characteristic of producers and sellers of jamu in Kampung Pejabat.

Table 2. Characteristic of the respondent.

\begin{tabular}{|c|l|c|c|c|}
\hline No & \multicolumn{1}{|c|}{ Characteristic } & Minimum & Maksimum & Average \\
\hline 1 & Age (years) & 28 & 65 & 46 \\
\hline 2 & Formal education & Elementary & High school & High school \\
\hline 3 & Experience in jamu processing (years) & 2 & 40 & 20 \\
\hline 4 & $\begin{array}{l}\text { The volume of } j a m u \text { processing (before } \\
\text { the pandemic) (litres) }\end{array}$ & 5 & 10 & 7,5 \\
\hline 5 & $\begin{array}{l}\text { The volume of } j a m u \text { processing (after } \\
\text { the pandemic) (litres) }\end{array}$ & 5 & 20 & 12,5 \\
\hline 6 & $\begin{array}{l}\text { The volume of } j a m u \text { processing (after } \\
\text { one year the pandemic) (litres) }\end{array}$ & 5 & 13 & 9 \\
\hline
\end{tabular}

Source: Primary data (2021)

The business of processing and selling jamu itself has been around since 1979. At first, it was only done by a few people, but many other residents are being jamu processors and sellers over time because the income is quite promising. Table 2 shows that the age of the respondents ranged from $28-65$ years, and almost 50 percent of jamu producers in Kampung Pejabat are the second generation with the age of 40 years and over. The respondents involved in jamu processing are generally still at the productive to unproductive period, which correlates with their experience in making jamu with an average of 20 years. Besides that, the respondent's average education level is high school. Even though the method of jamu processing for most Kampung Pejabat is still based on the traditional way, learned from generation to generation, they still accept innovations related to modern processing and marketing. It also underlies the city government's support for developing tourist areas in this location. This support is provided in processing equipment assistance, quality assistance, promotions, and more.

Most of jamu they processed is known as fresh jamu or jamu gendong. Fresh jamu is a traditional herbal drink freshly made from medicinal plant ingredients for immediate consumption. The name jamu gendong is given because the seller sells the product by carrying a basket on the back. Although many sellers of jamu are using motorbikes, the term jamu gendong is still used [19]. At least three fresh jamu are processed, i.e., jamu Kunyit Asem made from turmeric and tamarind, jamu Beras Kencur, made from rice and galangal, jamu Gula Jahe is made from ginger and brown sugar.

The production capacity of fresh jamu range from 5 - 10 litres per day, depending on the marketing area. Each producer of jamu in Kampung Pejabat already has their consumers and market area, so they sell their product by going directly to the consumers. Some producers pack their product in a bottle than be deposited in a stall or sold by resellers.

The condition of the Covid-19 pandemic has affected the processing and sale of fresh jamu as experienced by jamu producers in Kampung Pejabat, especially at the beginning of the pandemic. From the interview, the increased volume of production can reach almost $100 \%$ compared to the condition before the pandemic, and it occurs in jamu, which can boost the immune system. Consumers who usually only consume directly when the seller arrives are currently also stocking jamu in a bottle for consumption by family members. Other literature also states that the sale of jamu made from herbs produced by the small microbusiness (UKM) Jamu Raden at Sukabumi, West Java, has experienced a surge. It happened because the jamu was believed to increase the body's resistance to various diseases, not only 
COVID-19 [15]. Table 3 shows the financial analysis of jamu Gula Jahe processing before and during pandemic esspecially at the beginning.

Table 3. Financial analysis of jamu processing i.e Gula Jahe in Banjarbaru (before and during pandemic)

\begin{tabular}{|c|c|c|c|c|}
\hline \multirow[t]{2}{*}{ Description } & \multicolumn{2}{|c|}{$\begin{array}{c}\text { Basis } 10 \text { liters (before } \\
\text { pandemic) } 2019\end{array}$} & \multicolumn{2}{|c|}{$\begin{array}{c}\text { Basis } 20 \text { liters (during } \\
\text { pandemic) } 2020\end{array}$} \\
\hline & Amount & Value (Rp) & Amount & Value (Rp) \\
\hline $\begin{array}{ll}\text { A. } & \text { Raw material } \\
\text { - Ginger }(\mathrm{kg}) \\
\text { - Lemongrass }(\mathrm{kg}) \\
\text { - Cinnamons }(\mathrm{kg}) \\
\text { - Brown sugar }(\mathrm{kg}) \\
\text { - Sugar }(\mathrm{kg}) \\
\text { - Salt }(\mathrm{g}) \\
\text { TOTAL (A) }\end{array}$ & $\begin{array}{c}0,5 \\
0,5 \\
0,25 \\
0,125 \\
0,5 \\
0,5\end{array}$ & $\begin{array}{r}30.000 \\
15.000 \\
25.000 \\
6.500 \\
6.000 \\
500 \\
83.000\end{array}$ & $\begin{array}{c}1 \\
1 \\
0,5 \\
0,25 \\
1 \\
1\end{array}$ & $\begin{array}{r}100.000 \\
50.000 \\
50.000 \\
7.500 \\
12.500 \\
1.000 \\
221.000\end{array}$ \\
\hline 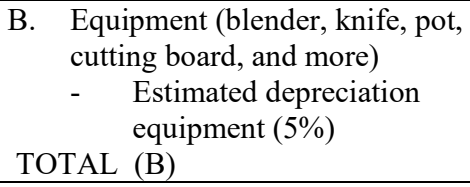 & & $\begin{array}{l}15.000 \\
15.000\end{array}$ & & $\begin{array}{l}15.000 \\
15.000 \\
\end{array}$ \\
\hline $\begin{array}{ll}\text { C. } & \text { Labor (family member) } \\
- & \text { Processing } \\
- & \text { Selling/marketing } \\
\text { TOTAL }(\mathrm{C}) & \end{array}$ & $\begin{array}{l}2 \\
2\end{array}$ & $\begin{array}{l}12.500 \\
12.500 \\
25.000\end{array}$ & $\begin{array}{l}2 \\
2\end{array}$ & $\begin{array}{l}25.000 \\
25.000 \\
50.000\end{array}$ \\
\hline $\begin{array}{l}\text { TOTAL Production cost }(\mathrm{A}+\mathrm{B}+\mathrm{C}) \\
\rightarrow \mathrm{Tc}\end{array}$ & & 123.000 & & 286.000 \\
\hline $\begin{array}{l}\text { REVENUE (liter) (Rp. 22.000/liter) } \\
\rightarrow \mathrm{R}\end{array}$ & 10 & 160.000 & 20 & 440.000 \\
\hline INCOME & & 37.000 & & 154.000 \\
\hline R/C Ratio & & 1,3 & & 1,54 \\
\hline
\end{tabular}

Source: Primary data (2021)

From Table 3, we can compare the income of jamu producers before the pandemic and during the pandemic. The increase in jamu production is about 100\% (10 liters to 20 liters per day), and the jamu price increase is about 37,5\% (Rp. 16.000/liter to Rp. $22.000 /$ liter). Even though there was an increase in production volume, their income didn't soar too high because the price of raw materials also increases. Most jamu producers obtain raw materials by growing their own. Still, they sometimes have to look for additional raw materials in the market or another place to produce jamu. If we look at the $\mathrm{R} / \mathrm{C}$ ratio with a value of 1,54 during the pandemic, this business is still feasible to continue. It means every 1 rupiah issued by the producers will generate 1,54 rupiah.

\section{Conclusion}

Preventive efforts avoid the virus done by the peoples at the beginning of the pandemic until now by consuming jamu. Around $82-88 \%$ of people consuming jamu that they bought or made themselves. They are also consuming others such as fruits, vegetables, and honey in smaller amounts. The peoples already know the benefits of jamu as herbal medicine because it is a hereditary knowledge. Besides, consuming jamu gendong does not require a high cost. There was an increase in volume production of jamu gendong around $100 \%$ during the pandemic compared with production before the pandemic. Even though there was an increase in volume production, their income didn't soar too high because raw materials' price also 
increased. The $\mathrm{R} / \mathrm{C}$ ratio of jamu processing is increased from 1,3 to 1,54 it means the pandemic had a positive impact on the jamu processing business, and this business is feasible to continue.

\section{References}

1. B.L. Zhong, W. Luo, H.M. Li, Q.Q. Zhang, X.G. Liu, W. T. Li, Yi Li, Int. J. Biol. Sci.16, 10, 1754-1752 (2020)

2. World Health Organization, 2019-nCoV outbreak is an emergency of international concern, https://www.euro.who.int/en/health-topics/health-emergencies/internationalhealth-regulations/news/news/2020/2/2019-ncov-outbreak-is-an-emergency-ofinternational-concern (2020) (access Mei, 2021)

3. Kompas.com, Announced early March, expert: Corona Virus enters Indonesia in early Januari, https://www.kompas.com/sains/read/2020/05/11/130600623/diumumkan-awalmaret-ahli--virus-corona-masuk-indonesia-dari-januari (2021)

4. Ministry of Health of Republic Indonesia, COVID-19 Prevention and Control Guidelines, (Pub. L. No. Kepmenkes No. HK 01.07/MENKES/413/2020, Jakarta, 2020)

5. Fathoni, M.N., J. Layanan Masy. 4, 2, 479-485 (2020)

6. J.M. Sanders, M.L. Monogue, T.Z. Jodlowski, JAMA. 323, 18, 1824-1836 (2020)

7. D.Hartanti, B.A. Dhiani, S.L. Charisma, R. Wahyuningrum, Pharm Sci Res, 7, 12-22 (2020)

8. Ministry of Health of Republic Indonesia, Ministry of health of Republic Indonesia suggest people use traditional medicine [in Bahasa], https://www.kemkes.go.id/article/view/20052100005/kemenkes-sarankan-masyarakatmanfaatkan-obat-tradisional.html (2020).

9. A.R. Kusumo, F.Y. Wiyoga, H.P. Perdana, I. Khairunnisa, R.I. Suhandi, S.S. Prastika, J. Pub. Serv. 4, 2, 465-471 (2020)

10. Andriati, Wahjudi, J.Masy. Kebud. dan Polit. 29, 3, (2016)

11. M.S. Perdani, A.K. Hasibuan, Bencoolen J. of Pharm 1, 1, 11-25 (2021)

12. Indonesian NADFC, Guidelines for The Use of Herbs and Health Supplements in Facing COVID-19 in Indonesia, National Agency of Drug and Food Control of Republic of Indonesia, https://online.flipbuilder.com/aeqr/texx/mobile/index.html (2020)

13. Swastika, JPPTP, 7, 1, 90-103 (2004)

14. Ministry of Health of Republic Indonesia, Kepmenkes RI No. HK.01.07/MENKES/382/2020 about Health Protocols for the Community in Public Places and Facilities in the Context of Prevention and Control of Corona Virus Desease 2019( COVID-19) (2020)

15. Susilawati, Hikmatulloh, J. Swabumi 9, 1, 57-63 (2021)

16. Mangkunegara, Prabu Anwar, Perilaku Konsumen (PT. Refika Aditama Bandung, 2002)

17. Firmansyah M. A., Perilaku Konsumen: Sikap dan Pemasaran (Qiara Media Publisher, 2019)

18. Umar S., Shah M.A.A., Munir M.T., Yaqoob M., Fiaz M., Anjum S., Kaboudi K., Bouzouaia M., Younus M., Nisa Q., Iqbal M., Umar W., Poult Sci. 95, 7, 1513 - 1520 (2016)

19. Ministry of Health of Republic Indonesia, Pembuatan Jamu Segar Yang Baik dan Benar (Directorate General of Pharmaceutical and Medical Devices Development, Jakarta, 2015) 